\title{
Media Pembelajaran Pengenalan Alat Transportasi, Musik, dan Benda di Sekolah bagi Siswa Tunarungu Sekolah Dasar
}

\author{
R Septiana ${ }^{1}$, F Y Al Irsyadi ${ }^{2}$ \\ Program Studi Informatika, Universitas Muhammadiyah Surakarta ${ }^{12}$ \\ Jl. A Yani Tromol Pos 1 Pabelan Kartasura, Jawa Tengah, 57162, Indonesia ${ }^{12}$ \\ 1200160079@student.ums.ac.id*1, fyai181@ums.ac.id ${ }^{2}$ \\ diterima: 10 Juli 2020 \\ direvisi: 6 September 2020 \\ dipublikasi: 1 Maret 2021
}

\begin{abstract}
Abstrak
Sekolah Luar Biasa-B (SLB) YRTRW Surakarta merupakan sekolah bagi anak-anak yang berkebutuhan khusus untuk membantu memberikan pendidikan awal. Berdasarkan survei terhadap SLB-B YRTRW Surakarta yaitu siswa masih sulit untuk menjabarkan nama benda dengan benar dan masih ada kekeliruan, selain itu siswa cenderung bermain dikarenakan metode pembelajaran kurang menarik sehingga tidak fokus terhadap materi yang disampaikan oleh guru. Alternatif atau solusinya yaitu dengan memberikan media pembelajaran dalam bentuk aplikasi. Aplikasi ini bernama BELMA (Belajar Bersama) mengenai pengenalan alat transportasi, alat musik, dan benda di lingkungan sekolah bagi siswa kelas empat sekolah dasar. Perancangan media pembelajaran edukasi menggunakan metode dengan melakukan observasi, analisis atau idenifikasi masalah, dan wawancara. Hasi penelitian berdasarkan kuesioner adalah $87,871 \%$, dengan demikian aplikasi ini dapat membantu proses belajar. Tujuan penelitian diharapkan dapat membantu guru maupun siswa dalam proses pembelajaran dikelas agar siswa dapat cepat memahami dan antusias yang tinggi terhadap penyampaian materi.
\end{abstract}

Kata kunci : Alat Transportasi; Tunarungu; Benda di Sekolah; Alat Musik

\begin{abstract}
A remarkable school -B (SLB) YRTRW Surakarta is a spesial school for children with special school for children with special needs to help provide education. According to a survey of SLB-B YRTRW Surakarta, it is difficult for students to get the names of objects right anf there are still mistakes, and it is also difficult for students to play because the learing methods are less interesting and therefore not focus on the material presented by teachers. An alternative or solution is to provide the learning media in the form of applications. The appication is called BELMA (together learning) abaout the introduction of transportation tools, Musical Instruments, and objects in the school environment for fourth-grade elementary school students. The founding of the media of education is a method for observation, analysis or problem identification, and interviews. The result of research based on questionnaires are $87.871 \%$, and this application can thus help the learning process. The purpose of this study is to be expected to help both tearchers and students in the learning process in class so that students can be quick to understand and enthusiastic about material delivery.
\end{abstract}

Keywords: Transport; Deaf; Item at School; Musical Instruments

\section{Pendahuluan}

SLB-B YRTRW Surakarta berada di Jl. Gumunggung, kec. Banjarsari, Kota Surakarta, sekolah tersebut dimulai dari tingkatan Taman kanak-kanak (TK) hingga Sekolah Menengah keatas (SMA), selain itu memiliki fasilitas asrama khusus perempuan, perpustakaan dan ruang komputer. Siswa kelas empat berjumlah 9 anak, dengan rentang umur yang berbedabeda, yang paling muda berumur 9 tahun dan yang dewasa 24 tahun. Pembelajaran yang digunakan oleh guru selain dengan papan tulis adalah uji praktek langsung dengan bantuan gambar dan alat musik sebagai media objeknya [1]. Anak tunarungu memiliki gangguan pada indera pendengarannya, sehingga mempengaruhi prestasi akademik dikarenakan 
kurangnya kosa kata maupun memahami makna dari suatu kata [2]. Penggunaan bahasa isyarat yang digunakan adalah BISINDO (Bahasa Isyarat Indonesia) sebagai bahasa komunikasi sehari - hari bagi ABK (Anak Berkebutuhan Khusus) dengan gerakan tubuh dan juga ekspresi atau mimik wajah [3].

Pengenalan nama benda sudah dilakukan saat kelas satu sampai kelas enam sekolah dasar, anak tunarungu masih bisa mendengar walaupun sedikit, karena masih ada sisa pendengaran yang dimiliki, dan tiap anak juga memiliki tingkatan pendengaran yang berbeda-beda. Pembelajaran pencapaian materi yang sudah dilakukan, akan diulang kembali di kelas artikulasi dengan tujuan untuk melatih dan meningkatkan kosa kata maupun pengenalan benda di lingkungan sekolah [4]. Permasalahan yang ada di SLB-B adalah minimnya pengenalan terhadap nama-nama benda, memahami kata atau kalimat suatu pertayaan.

Keutamaan yang diperhatikan adalah siswa dapat membaca dan menulis di mana keduanya saling berkaitan dan merupakan pencapaian bagi siswa agar dapat memahami makna kata yang mereka baca termasuk kemampuan bahasa dasar [5]. Berdasarkan hasil observasi di SLB-B YRTRW Surakarta pada minggu kedua bulan September, yaitu beberapa siswa ternyata masih sulit untuk menyebutkan nama benda tertentu dan masih terbalik ketika menjabarkan kata per kata dari benda dan keterangan pada saat latihan menulis yang dipaparkan oleh guru. Selain itu, untuk membaca mereka sudah bisa hanya saja masih belum mengerti maksud dari kalimat yang mereka baca.

Sistem pembelajaran yang digunakan guru kepada siswa memiliki media pembelajaran tersendiri, sehingga proses pembelajaran menjadi lebih menarik serta mengetahui tingkat antusias dari masing-masing siswa [6]. Sampai saat ini pembelajaran manual mulai berkembang dengan media teknologi yang bertujuan untuk mempermudah dan meningkatkan pemahaman materi, meskipun dibeberapa sekolah belum menerapkan sistem teknologi dikarenakan fasilitas yang belum memadai. Solusi terkait masalah tersebut ialah dengan membangun teknologi yaitu aplikasi media pembelajaran edukasi dengan fitur gambar, suara, dan berbagai penyelesaian dalam bentuk permainan dengan interface yang menarik [7].

Hasil pada penelitian ini adalah media pembelajaran BELMA telah diaplikasikan atau digunakan di SLB-B YRTRW untuk media pembelajaran. Tujuan penelitian yaitu untuk membantu proses pembelajaran tentang pengenalan alat transportasi, alat musik dan benda di lingkungan sekolah, oleh guru maupun wali murid tanpa menghilangkan peran keduannya dalam proses belajar mengajar, selain itu meningkatkan ketertarikan setiap siswa terhadap pelajaran bervariasi, tetapi jika mereka mulai menyukai pelajaran tersebut maka akan timbul rasa ingin tahu untuk memperluas pengetahuannya [8].

\section{Kajian Pustaka}

Media pembelajaran merupakan hal yang menyenangkan untuk mengisi waktu luang siswa ketika sedang merasa bosan atau sekedar untuk menghibur diri ketika berada di rumah, oleh sebab itu adanya perancangan media pembelajaran edukasi untuk siswa [7], seperti pada paper R. Nuqisari, dkk. Sesuatu yang disukai oleh siswa adalah bermain, seperti yang dikatakan pada paper H. A. Emka [9] karena dapat bermain bersama teman- teman di lingkungan sekolah, oleh sebab itu perlu adanya media pembelajaran yang interaktif salah satunya dengan media pembelajaran edukasi, [8] seperti pada paper F. Yasin, A. Irsyadi, dkk.

Paper A. H. Wagino menyatakan Anak tunarungu memiliki ganguan pada pendengarannya sehingga kurang dapat mendengar dengan baik [6]. Siswa sekolah luar biasa yang menuntut ilmu untuk diimplementasikan di kehidupan dimulai dari nol, dengan keterbatasan yang mereka miliki dibandingkan anak-anak pada umumnya. Pembelajaran 
yang dilakukan untuk menarik perhatian siswa adalah dengan menggunakan berbagai teknik seperti adanya gambar dan dibuat seperti permainan. Adanya metode pembelajaran yang menarik tersebut dapat meningkatkan antusias siswa sehingga senang saat pembelajaran berlangsung.

Pengenalan yang telah diajarkan ketika masih kecil merupakan bentuk awal proses belajar anak [10], seperti pada paper M. Adiwijaya, K. I. S, dkk. Siswa tunarungu memiliki kesulitan dalam belajar seperti merangkai kata yang masih keliru dan juga saat membaca sebuah kalimat mereka belum mengerti dengan maksud kalimat tersebut, sehingga dapat mempengaruhi proses belajar mereka.

\section{Metode Penelitian}

Metode Penelitian yang digunakan untuk membangun aplikasi media pembelajaran adalah melalui observasi yang memiliki beberapa tahapan seperti pada Gambar 1 yang merupakan Diagram alur tahapan penelitian.

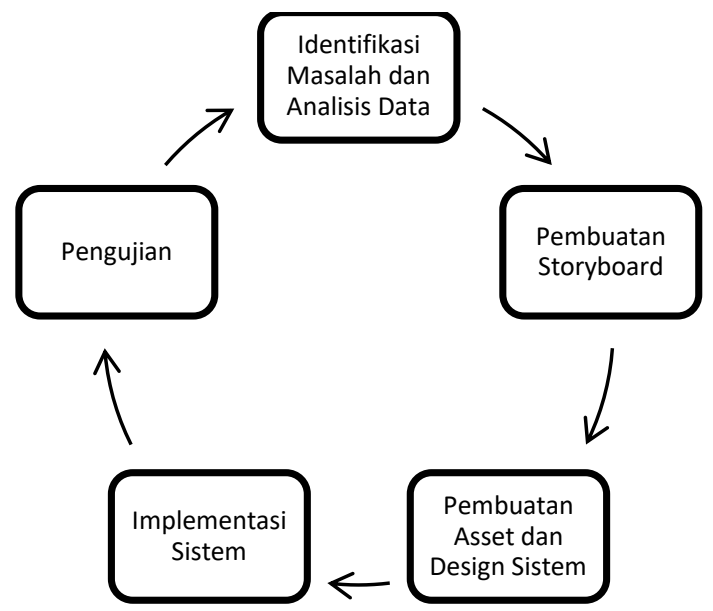

Gambar 1. Diagram Alur Tahapan Penelitian

Berikut penjelasan alur dari tahapan penelitian sebagai berikut :

1. Identifikasi Masalah dan Analisis Data

Perancangan media pembelajaran edukasi ini, menggunakan teknik pengumpulan data dengan melakukan observasi di kelas artikulasi, untuk mengetahui kemampuan setiap anak ketika pembelajaran berlangsung, serta melakukan wawancara dengan wali kelas 4 mengenai perkembangan siswa-siswi maupun masalah yang ada saat pembelajaan dikelas. Berdasarkan hasil wawancara dan observasi yang telah dilakukan dengan guru pengampu di SLB-B YRTRW Surakarta, data yang didapatkan sebagai berikut :

a. Beberapa siswa masih perlu bimbingan lebih untuk dapat mengikuti pembelajaran dikelas. Serta membutuhkan alat bantu seperti gambar.

b. Penggunaan kurikulum disekolah mengikuti kurikulum yang dikeluarkan oleh kemendikbud (kementrian pendidikan dan budaya)

c. Bahasa isyarat yang digunakan menggunakan SIBI (Sistem Isyarat Bahasa Indonesia).

d. Siswa/siswi diharapkan mampu melafalkan huruf vocal atau bahasa lisan (Oral).

2. Pembuatan Storyboard

Sebelum pembuatan aplikasi dilakukan perlu adanya sebuah gambaran umum atau ilustrasi aplikasi yang menjelaskan alur permainan dari awal sampai akhir atau yang biasa disebut storyboard (Emka, 2017). Storyboard ini dapat dilihat pada gambar II. 


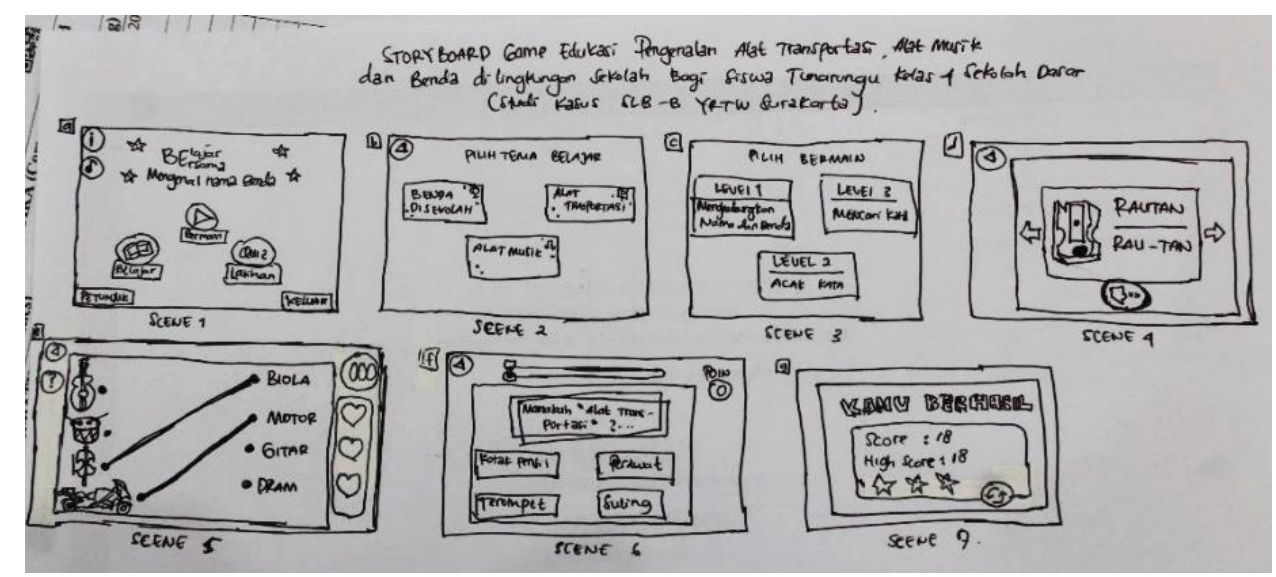

Gambar 2. Storyboad Aplikasi

Penjelasan Berdasakan storyboard pada gambar 2 adalah Scene 1, layout utama,memiliki tombol informasi, musik, petunjuk, play (bermain), belajar, keluar dan quiz (latihan) dimana setiap tombol akan menuju ke layout menu lainnya. Scene 2, pilih tema belajar ada 3 kelompok yaitu alat transportasi, alat musik, dan benda di lingkungan sekolah. Scene 3, layout pilih bermain, level 1 menghubungkan nama dan benda, level 2 acak kata, dan level 3 mencari kata. Scene 4, layout belajar dengan metode slide image untuk melihat gambar selanjutnya. Scene 5, layout bermain level 1 menunjukkan gambar dan nama benda yang akan dihubungkan sesuai dengan nama benda tersebut dengan benar. Scene 6, tampilan Quiz, soal ada 20 dan durasi waktu. Scene 7, popup skor berupa hasil penilaian jawaban yang benar. Skor quiz, hasil yang akan ditampilkan yang benar dan mendapat bintang 3 jika semua jawaban benar

\section{Pembangunan Aset dan Design Sistem}

Asset merupakan gambar maupun tombol yang akan dijadikan sebagai user interface menarik pada aplikasi tersebut.pembuatan asset ini menggunakan software Corel Draw, maupun scan gambar buku panduan SLB-B, dan beberapa tombol mengambil di situs Freepik. Perancangan media pembelajaran edukasi ini menggunakan tools construct 2 berbasis HTML 5 untuk merancang permainan dan Corel Draw sebagai media pendukung ketika desain huruf maupun gambar (Adiwijaya, S, \& Christyono, 2015).

\section{Pengujian}

Tahap pengujian ini, akan dilakukan uji blackbox terhadap sistem, serta demo aplikasi kepada guru, dan melakukan testing media pembelajaran edukasi kepada siswa/i SLB-B YRTRW Surakarta. Setelah itu akan dilakukan pengujian kembali dengan pre-test dan post-test untuk mengetahui tolak ukur dari pemahaman siswa/i terhadap media pembelajaran edukasi, sebagai perbandingan dengan metode manual.

\section{Hasil dan Pembahasan}

Penelitian ini menghasilkan media pembelajaran edukasi berupa aplikasi pengenalan alat transportasi, alat musik, dan benda dilingkungan sekolah bagi siswa/i kelas 4 di SLB-B YRTRW Surakarta. Berikut adalah pembahasan dan prosedur aplikasi BELMA (Belajar bersama mengenal nama benda).

\subsection{Implementasi Aplikasi}


Aplikasi Belma (Belajar bersama) ini dikembangkan menggunakan software construct 2, yang dapat dijalankan melalui android dan windows.

\subsubsection{Layout Menu Utama Aplikasi}

Menu utama seperti pada gambar 3, terdiri dari 7 tombol. Tombol informasi berisi mengenai credits aplikasi, tombol musik untuk background, tombol petunjuk berisi fungsi semua tombol pada aplikasi, tombol belajar akan masuk ke tema belajar, tombol bermain akan masuk ke layout pilih bermain, tombol latihan berisi soal-soal mengenai semua materi, dan tombol keluar untuk menutup aplikasi.

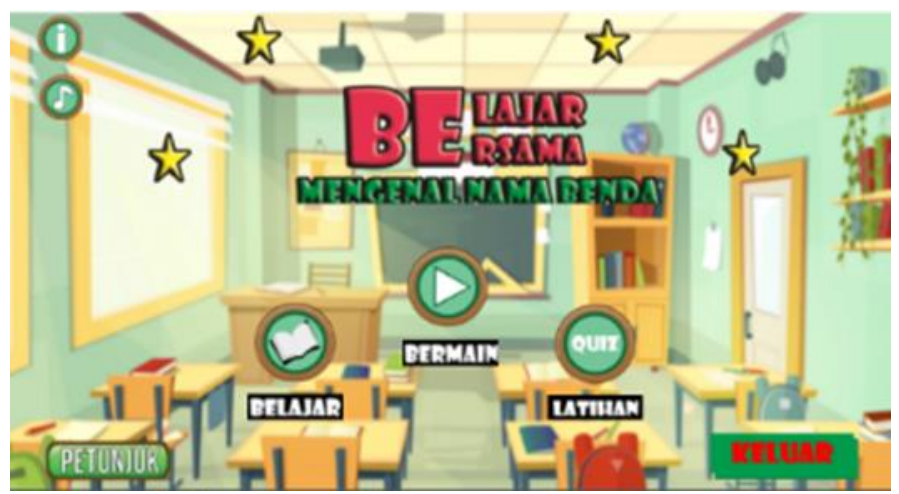

Gambar 3. Menu utama

\subsubsection{Layout Petunjuk}

Layout Petunjuk pada gambar 4, terdapat dua tombol yaitu tombol selanjutnya yang akan pindah ke layout petunjuk lain, dan tombol home yang akan menuju ke layout utama aplikasi. Layout informasi, berisi credits mengenai tools dan asset gambar yang digunakan, terdapat satu tombol kembali yang akan pindah ke layout utama aplikasi.

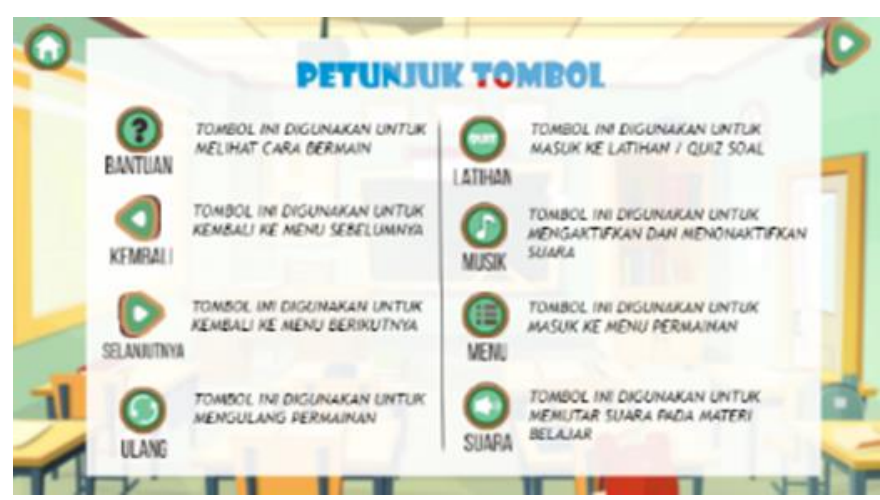

(a) Layout petunjuk tombol 


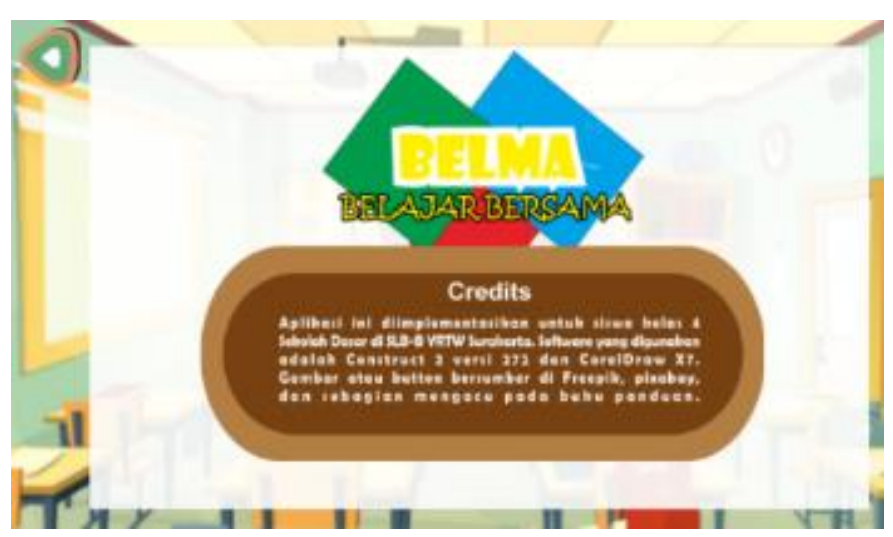

(b) Layout Informasi

Gambar 4. Tampilan Petunjuk dan informasi

\subsubsection{Layout pilih tema belajar}

Menu pilih tema belajar dan bermain pada gambar 5, terdapat satu tombol kembali yang akan masuk ke menu utama dan ada 3 sub menu belajar yaitu benda di sekolah, alat musik, dan alat transportasi. Jika sub menu benda disekolah diklik maka akan ke layout belajar yang bisa dilihat pada gambar 5. Menu pilih bermain, ada tingkatan level yaitu level 1 menghubungkan nama dan benda, level 2 acak kata, dan level 3 mencari kata.

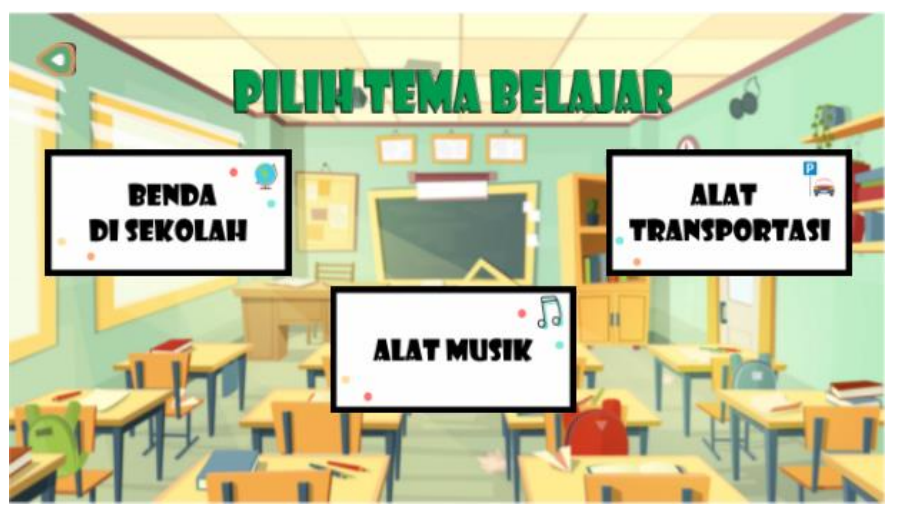

(a) Layout tema belajar

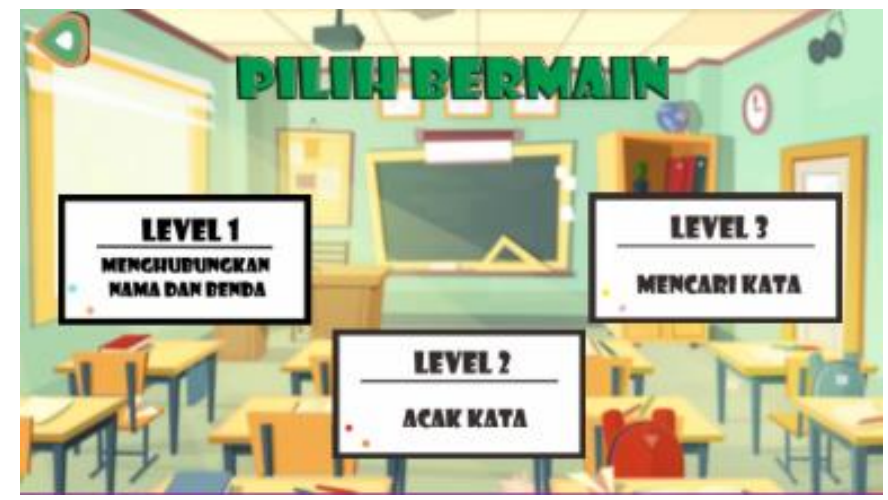

(b) Layout bermain

Gambar 5. Menu pilih tema belajar dan bermain

\subsubsection{Layout Belajar benda di sekolah}

Layout belajar pada gambar 6, terdapat empat tombol, tombol kembali akan masuk ke menu pilih tema belajar, tombol panah kiri akan menampilkan gambar sebelumnya dan 
tombol kanan akan menampilkan gambar setelahnya, tombol audio akan mengeluarkan suara nama benda yang tampil.

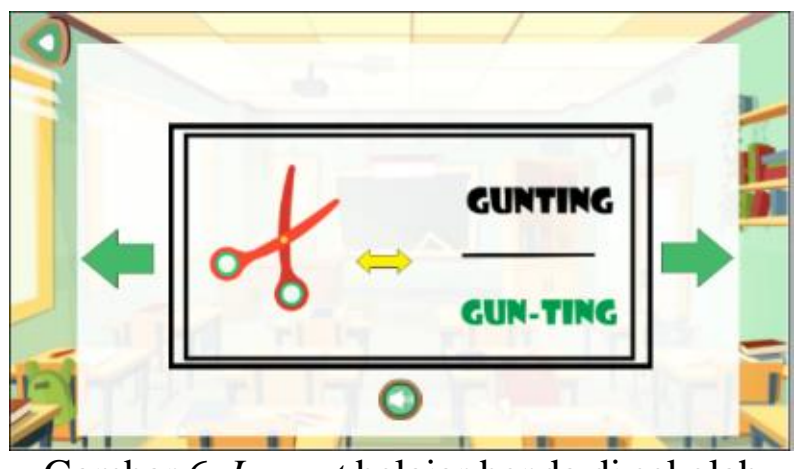

Gambar 6. Layout belajar benda di sekolah

\subsubsection{Layout menghubungkan nama dan benda}

Menu level 1 pada gambar 7, terdapat dua tombol yaitu tombol kembali yang akan ke layput pilih bermain, tombol bantuan untuk menampilkan cara bermain, dan ada 4 item benda dengan nama yang acak, pada permainan ini user akan menghubungkan nama dan benda yang sesuai.

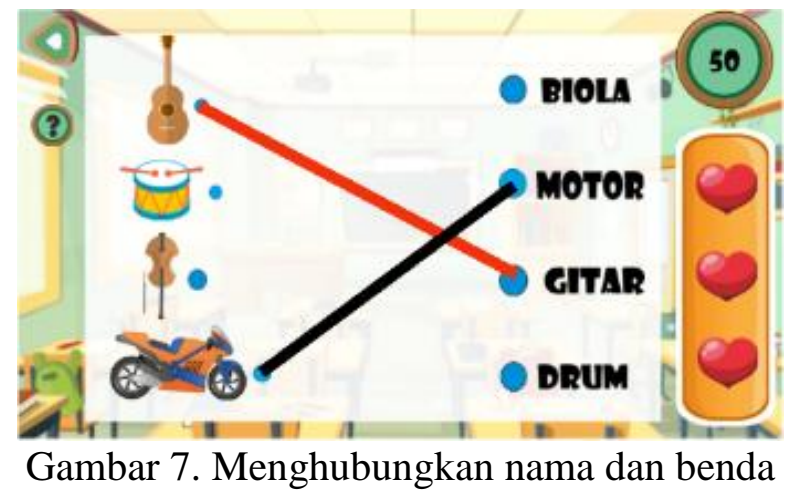

\subsubsection{Layout acak kata}

Acak kata pada gambar 8, terdapat dua tombol yaitu tombol kembali yang akan ke layout pilih bermain, tombol bantuan menampilkan cara bermain, dan user akan melakukan drag and drop huruf yang acak untuk meletakkan pada lingkaran agar menjadi susunan nama sesuai dengan gambar tersebut.

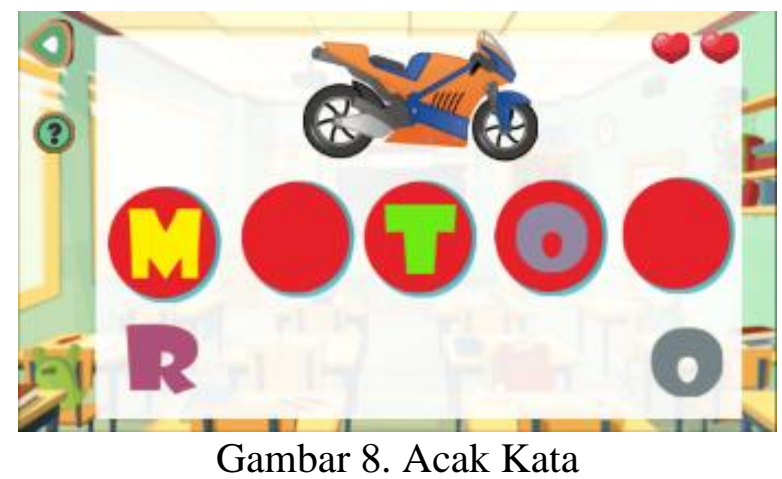




\subsubsection{Layout mencari kata}

Acak kata pada gambar 9, terdapat dua tombol yaitu tombol kembali yang akan ke layout pilih bermain, tombol bantuan yang akan menampilkan cara bermain, dan user akan mencari kata yang berdasarkan benda yang sudah disediakan di dalam kata yang sudah acak.

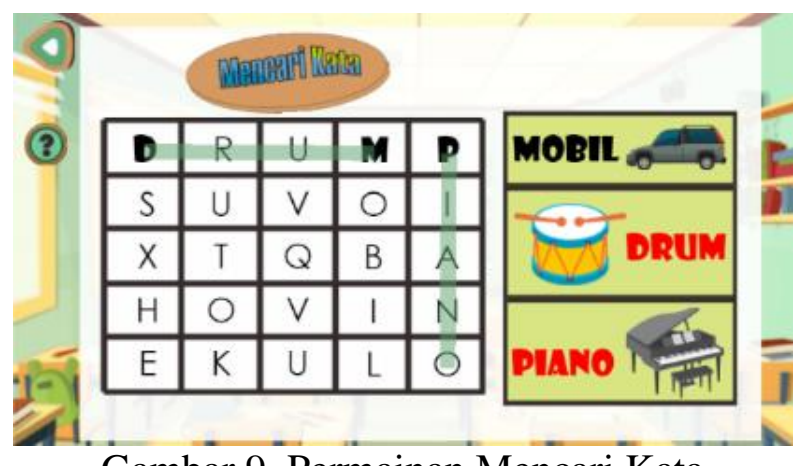

Gambar 9. Permainan Mencari Kata

\subsubsection{Layout quiz atau latihan}

Layout quiz atau latihan pada gambar 10, terdapat satu tombol kembali yang akan ke layout utama aplikasi, ada 20 soal tersedia dan empat pilihan jawaban yang akan dikerjakan oleh user dan waktu untuk mengerjakan soal dengan total poin berdasarkan jawaban benar.

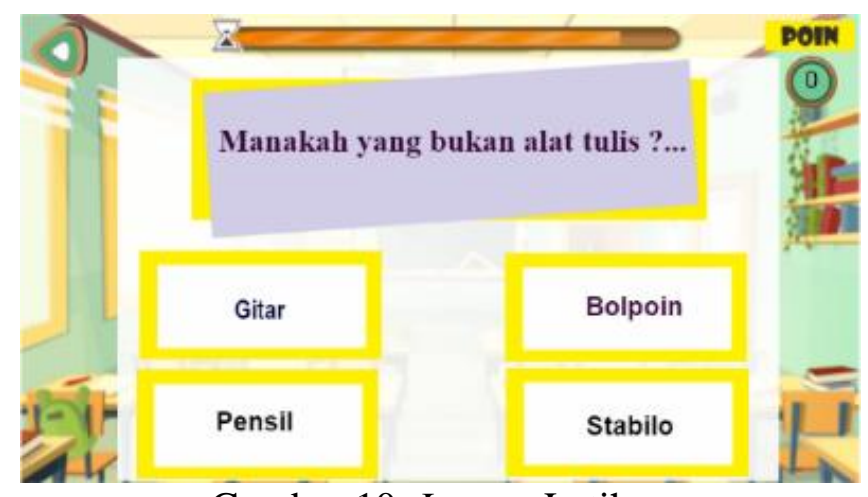

Gambar 10. Layout Latihan

\subsubsection{Layout keluar}

Tampilan keluar menampilkan pop up pertanyaan dengan dua tombol ya dan tidak, jika ya maka akan menutup aplikasi dan jika tidak tetap berada di halaman utama.

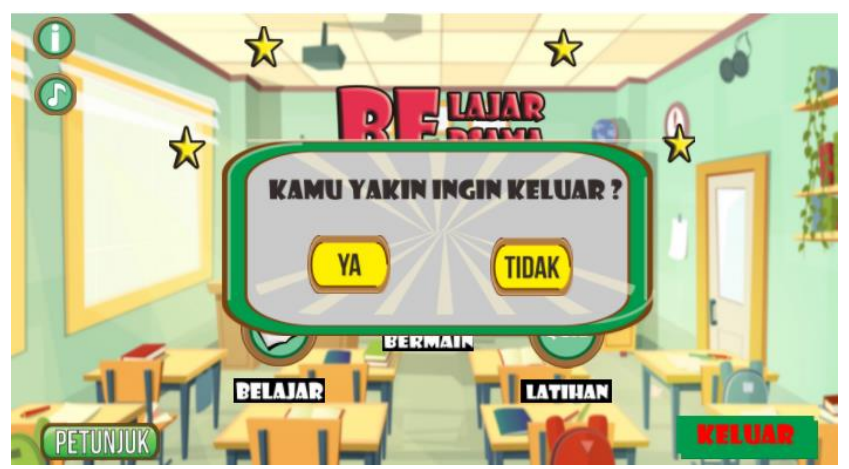

Gambar 13. Pop up keluar 


\subsection{Pengujian}

Pengujian aplikasi dilakukan dengan memaparkan Belma (belajar bersama) kepada siswa-siswi kelas 4 sekolah dasar didampingi oleh guru pendamping. Sebelumnya akan dilakukan pre-test serta post test, dan pengujian blackbox terhadap aplikasi dan juga User Acceptance Test dari pengguna.

\subsubsection{Pengujian blackbok}

Pengujian blackbox ini merupakan pengujian yang dilakukan oleh pengembang untuk memastikan semua tombol maupun fungsinya sudah sesuai dengan yang diharapkan. Pengujian blackbox dapat dilihat pada tabel 1.

Tabel 1. Pengujian Blackbox

\begin{tabular}{|c|c|c|c|c|}
\hline No & Kasus/diuji & Skenario Uji & Hasil yang diharapkan & $\begin{array}{c}\text { Hasil } \\
\text { Pengujian }\end{array}$ \\
\hline 1. & $\begin{array}{l}\text { Tombol } \\
\text { Belajar }\end{array}$ & $\begin{array}{l}\text { Klik tombol menu } \\
\text { belajar }\end{array}$ & $\begin{array}{l}\text { Menuju ke tampilan } \\
\text { menu tema belajar }\end{array}$ & Valid \\
\hline 2. & $\begin{array}{l}\text { Tombol } \\
\text { Bermain }\end{array}$ & $\begin{array}{l}\text { Klik tombol menu } \\
\text { bermain }\end{array}$ & $\begin{array}{l}\text { Menuju ke tampilan } \\
\text { menu tema bermain }\end{array}$ & Valid \\
\hline 3. & $\begin{array}{l}\text { Tombol } \\
\text { Quiz/Latihan }\end{array}$ & $\begin{array}{l}\text { Klik tombol menu } \\
\text { Quiz/latihan }\end{array}$ & $\begin{array}{l}\text { Manuju ke tampilan } \\
\text { quiz/latihan soal }\end{array}$ & Valid \\
\hline 4. & $\begin{array}{l}\text { Tombol } \\
\text { musik }\end{array}$ & Klik tombol musik & $\begin{array}{l}\text { Musik yang klik dapat } \\
\text { aktif atau mati. }\end{array}$ & Valid \\
\hline 5. & $\begin{array}{l}\text { Tombol } \\
\text { petunjuk }\end{array}$ & Klik tombol petunjuk & $\begin{array}{l}\text { Menuju ke tampilan } \\
\text { petunjuk tombol aplikasi }\end{array}$ & Valid \\
\hline 6. & $\begin{array}{l}\text { Tombol } \\
\text { Informasi }\end{array}$ & Klik tombol informasi & $\begin{array}{l}\text { Menuju ke tampilan } \\
\text { informasi }\end{array}$ & Valid \\
\hline 7. & $\begin{array}{l}\text { Tombol } \\
\text { keluar }\end{array}$ & $\begin{array}{l}\text { Klik tombol Exit } \\
\text { Permainan }\end{array}$ & $\begin{array}{l}\text { Menampilkan pop up } \\
\text { "kamu yakin ingin keluar } \\
\text { ?" }\end{array}$ & Valid \\
\hline 8. & Tombol ulang & Klik tombol ulang & $\begin{array}{l}\text { Restart layout yang } \\
\text { dimainkan }\end{array}$ & Valid \\
\hline 9. & Tombol menu & Klik tombol menu & $\begin{array}{l}\text { Menuju ke tampilan } \\
\text { menu bermain }\end{array}$ & Valid \\
\hline 10. & $\begin{array}{l}\text { Tombol } \\
\text { selanjutnya }\end{array}$ & Klik tombol selanjutnya & $\begin{array}{l}\text { Menuju ke layout } \\
\text { selanjutnya }\end{array}$ & Valid \\
\hline 11. & $\begin{array}{l}\text { Tombol } \\
\text { kembali }\end{array}$ & Klik tombol kembali & $\begin{array}{l}\text { Menuju ke layout } \\
\text { sebelumnya }\end{array}$ & Valid \\
\hline 12. & $\begin{array}{l}\text { Drag drop } \\
\text { objek }\end{array}$ & $\begin{array}{l}\text { Menyentuh, menekan } \\
\text { drag dan drop pada } \\
\text { objek dalam permainan }\end{array}$ & $\begin{array}{l}\text { Mengikuti arah dari } \\
\text { objek yang di-drag dan } \\
\text { drop }\end{array}$ & Valid \\
\hline \multirow[t]{3}{*}{13.} & \multirow{3}{*}{ Tema Belajar } & $\begin{array}{l}\text { a. Klik menu tema alat } \\
\text { transportasi }\end{array}$ & $\begin{array}{l}\text { Menuju ke tampilan } \\
\text { pengenalan alat } \\
\text { trasnportasi }\end{array}$ & Valid \\
\hline & & $\begin{array}{l}\text { b. Klik menu tema alat } \\
\text { musik }\end{array}$ & $\begin{array}{l}\text { Menuju ke tampilan } \\
\text { pengenalan alat musik }\end{array}$ & Valid \\
\hline & & $\begin{array}{l}\text { c. Klik menu tema } \\
\text { benda di sekolah }\end{array}$ & $\begin{array}{l}\text { Menuju ke tampilan } \\
\text { pengenalan benda } \\
\text { disekolah }\end{array}$ & Valid \\
\hline
\end{tabular}




\begin{tabular}{|c|c|c|c|c|}
\hline \multirow[t]{3}{*}{14.} & \multirow{3}{*}{$\begin{array}{c}\text { Tema } \\
\text { Bermain }\end{array}$} & $\begin{array}{l}\text { a. Klik menu tema } \\
\text { menghubungkan } \\
\text { nama dan benda }\end{array}$ & $\begin{array}{l}\text { Menuju ke tampilan } \\
\text { bermain menghubungkan } \\
\text { nama dan benda }\end{array}$ & Valid \\
\hline & & $\begin{array}{l}\text { b. Klik menu tema acak } \\
\text { kata }\end{array}$ & $\begin{array}{l}\text { Menuju ke tampilan } \\
\text { bermain acak kata }\end{array}$ & Valid \\
\hline & & $\begin{array}{l}\text { c. Klik menu tema } \\
\text { mencari kata }\end{array}$ & $\begin{array}{l}\text { Menuju ke tampilan } \\
\text { bermain mencari kata }\end{array}$ & Valid \\
\hline 15. & Tombol Suara & Klik tombol Suara & $\begin{array}{l}\text { Muncul suara object } \\
\text { yang diklik }\end{array}$ & Valid \\
\hline
\end{tabular}

Berdasarkan hasil pengujian blakbox tersebut, semua fungsi dari tombol aplikasi sudah valid dan sesuai dengan yang diharapkan oleh pengambang.

\subsubsection{Pengujian Smartphone Android}

Aplikasi media pembelajaran edukasi akan dilakukan build android, sehinnga bisa digunakan pada Smartphone, pengujian dapat dilihat pada gambar 11.

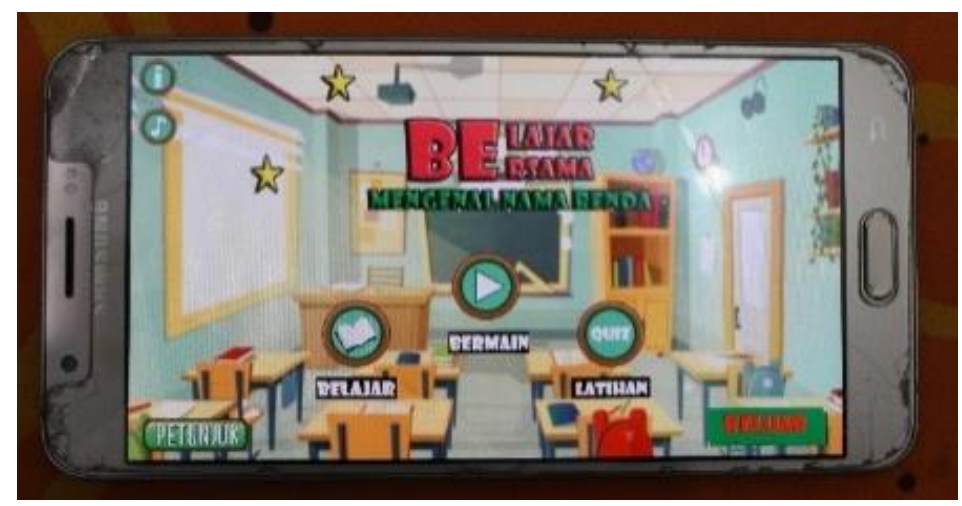

Gambar 11. Pengujian Smartphone Android

Pengujian pada Smartphone Android yaitu Redmi Note 7 versi 9.0 Lollipop, Samsung A6 versi 9.0 Lollipop, Samsung J7 versi 8.1 Oreo, Mi Note 5 pro ver 9.0 Lollipop ,berdasarkan data pengujian tersebut semua berjalan dengan dengan baik, hanya saja untuk Mi Note 5 pro dan Redmi Note 7 versi 9.0 baground permainan tidak full screen.

\subsubsection{Uji User Accaptance Test}

Pengujian ini dilakukan oleh pengguna sebagai penilaian berdasarkan media pembelajaran yang sudah diujikan, sehingga aplikasi sudah sesuai dengan kebutuhan. Selain itu dengan adanya pengguna juga dapat memberikan respon terhadap semua fitur maupun tampilan dari apalikasi media pembelajaran edukasi tersebut [11] . Quesioner ini diberikan kepada siswa sebagai pengguna yang berjumlah 8 orang, untuk memberikan pendapat terhadap aplikasi. Pertanyaan untuk siswa kelas 4 SLB-B YRTRW Surakarta dapat dilihat pada tabel 2.

Tabel 2. User Acceptance Test oleh siswa

\begin{tabular}{|l|l|c|c|c|c|c|c|}
\hline \multirow{2}{*}{ No } & \multicolumn{2}{|c|}{ Pertanyaan } & \multicolumn{4}{c|}{ Penilaian } & \multirow{2}{*}{ Jumlah } \\
\cline { 3 - 7 } & & SS & S & N & TS & STS & \\
\hline 1. & Tampilan dari aplikasi menarik. & 6 & 2 & 0 & 0 & 0 & 8 \\
\hline 2. & Menu di aplikasi mudah dipahami. & 5 & 3 & 0 & 0 & 0 & 8 \\
\hline 3. & Aplikasi mudah dimainkan. & 4 & 4 & 0 & 0 & 0 & 8 \\
\hline
\end{tabular}




\begin{tabular}{|l|l|c|c|c|c|c|c|}
\hline 4. & $\begin{array}{l}\text { Aplikasi dapat membantu dalam belajar } \\
\text { siswa. }\end{array}$ & 2 & 6 & 0 & 0 & 0 & 8 \\
\hline 5. & Petunjuk permainan dalam aplikasi jelas. & 0 & 4 & 0 & 4 & 0 & 8 \\
\hline 6. & Materi Pelajaran sudah dipelajari oleh siswa. & 7 & 1 & 0 & 0 & 0 & 8 \\
\hline 7. & $\begin{array}{l}\text { Aplikasi ini meningkatkan kemampuan anak } \\
\text { untuk pengenalan alat transportasi, alat } \\
\text { musik dan benda disekolah. }\end{array}$ & 4 & 4 & 0 & 0 & 0 & 8 \\
\hline 8. & $\begin{array}{l}\text { Menu yang disediakan memenuhi kebutuhan } \\
\text { siswa. }\end{array}$ & 2 & 6 & 0 & 0 & 0 & 8 \\
\hline
\end{tabular}

Berdasarkan User Acceptance Test yang diberikan pada tabel 2, selanjutnya melakukan pembobotan dapat dilihat pada tabel 3 dan menghitung hasil pengujian pada tabel 4 .

Tabel 3. Pembobotan jawaban quesioner

\begin{tabular}{|l|c|}
\hline \multicolumn{1}{|c|}{ Jawaban } & Bobot \\
\hline SS : Sangat Setuju & 5 \\
\hline S : Setuju & 4 \\
\hline N : Netral & 3 \\
\hline TS : Tidak Setuju & 2 \\
\hline STS : Sangat Tidak Setuju & 1 \\
\hline
\end{tabular}

Tabel 4. Hasil Pembobotan

\begin{tabular}{|l|l|c|c|c|c|c|c|}
\hline \multirow{2}{*}{ No } & \multicolumn{1}{|c|}{ Pertanyaan } & \multicolumn{5}{c|}{ Penilaian } & \multirow{2}{*}{ Jumlah } \\
\cline { 3 - 7 } & & SS & S & N & TS & STS & \\
\hline 1. & Tampilan dari aplikasi menarik. & 30 & 8 & 0 & 0 & 0 & 38 \\
\hline 2. & Menu di aplikasi mudah dipahami. & 25 & 12 & 0 & 0 & 0 & 37 \\
\hline 3. & Aplikasi mudah dimainkan. & 20 & 16 & 0 & 0 & 0 & 36 \\
\hline 4. & $\begin{array}{l}\text { Aplikasi dapat membantu dalam belajar } \\
\text { siswa. }\end{array}$ & 10 & 24 & 0 & 0 & 0 & 34 \\
\hline 5. & Petunjuk permainan dalam aplikasi jelas. & 0 & 16 & 0 & 8 & 0 & 24 \\
\hline 6. & $\begin{array}{l}\text { Materi pelajaran sudah dipelajari oleh } \\
\text { siswa. }\end{array}$ & 35 & 4 & 0 & 0 & 0 & 39 \\
\hline 7. & $\begin{array}{l}\text { Aplikasi ini meningkatkan kemampuan } \\
\text { anak untuk pengenalan alat transportasi, } \\
\text { alat musik dan benda disekolah. }\end{array}$ & 20 & 16 & 0 & 0 & 0 & 36 \\
\hline 8. & $\begin{array}{l}\text { Menu yang disediakan memenuhi } \\
\text { kebutuhan siswa. }\end{array}$ & 10 & 24 & 0 & 0 & 0 & 34 \\
\hline
\end{tabular}

Berdasarkan Tabel 4, dapat disimpulkan sebagai berikut :

a. Pertanyaan (1) : jumlah terhadap responden adalah 38. Nilai rata-rata adalah 4,75. Kemudian presentase nilainya adalah $95 \%$.

b. Pertanyaan (2) : jumlah terhadap responden adalah 37 . Niali rata-rata adalah 4,625. Kemudian presebtase nilainya adalah $92,5 \%$.

c. Pernyataan (3) : jumlah terhadap responden adalah 36. Nilai rata-rata adalah 4,5. Kemudian presentase nilainya adalah $90 \%$.

d. Pertanyaan (4) : jumlah terhadap responden adalah 34. Nilai rata-rata adalah 4,25.

Kemudian presentase nilainya adalah $85 \%$. 
e. Pertanyaan (5) : jumlah terhadap responden adalah 24. Nilai rata-rata adalah 3. Kemudian presentase nilainya adalah $60 \%$.

f. Pertanyaan (6) : jumlah terhadap responden adalah 39. nilai rata-rata adalah 4,875.kemudian presentase nilainya adalah $97.5 \%$.

g. Pertanyaan (7) : jumlah terhadap responden adalah 36. Nilai rata-rata adalah 4,5. Kemudian presentase nilainya adalah $90 \%$.

h. Pertanyaan (8) : jumlah terhadap respnden adalah 34. Nilai rata-rata adalah 4,25. Kemudian presentase nilainya adalah $85 \%$.

Perhitungan keseluruhan atau rata-rata jumlah pertanyaan pada quesioner tersebut adalah $86,875 \%$.

\section{Kesimpulan}

Penelitian ini telah membangun aplikasi yaitu media pembelajaran edukasi BELMA (Belajar Bersama) untuk membantu mempermudah pembelajaran di sekolah. Siswa - siswi dapat menggunakan aplikasi dengan baik. Berdasarkan hasil uji blackbox semua fitur berjalan dengan baik, dan untuk pengujian User Accaptence Test didapat rata-rata adalah $86,875 \%$, yang berarti aplikasi ini dapat membantu siswa mengenai pengenalan nama benda disekolah, alat musik dan alat transportasi. Aplikasi ini dapat digunakan kedalam android maupun dekstop.

\section{Daftar Pustaka}

[1] A. Kristoffersen, E. Simonsen, A. Kristoffersen, and E. Simonsen, "Communities of Practice: Literacy and Deaf Children Communities of Practice: Literacy and Deaf Children," J. Deaf Stud. Deaf Educ., vol. 3154, no. August, pp. 326-335, 2016.

[2] O. G. Setyawan, "Pengaruh Penggunaan Media Teka-Teki Silang Bergambar Terhadap Penguasaan Kosakata Peserta," Ortopedagogia, vol. 1, p. 7, 2015.

[3] R. A. Pranatadesta, "Indonesian Sign Language ( BISINDO ) Translation System with ORB for Bilingual Language," 2019 Int. Conf. Artif. Intell. Inf. Technol., pp. 502-505, 2019.

[4] C. A. Davenport, S. R. Alber-morgan, S. M. Clancy, and M. P. Kranak, "Effects of a Picture Racetrack Game on the Expressive Vocabulary of Deaf Preschoolers," J. Deaf Stud. Deaf Educ., vol. 22, no. 2008, pp. 326-335, 2017.

[5] S. Hadi and O. Özdemir, "Development of Learning Software for Deaf: A Sample of Language Learning Material,” Int. J. Eng. Res. Technol., vol. 6, no. 06, pp. 35-40, 2017.

[6] A. H. Wagino, "Video Game Edukatif Terhadap Kemampuan Mengenal Diajukan kepada Universitas Negeri Surabaya Video Game Edukatif Terhadap Kemampuan Mengenal Anggota Tubuh Manusia Pada Anak Tunarungu Kelas I,” J. Pendidik. Khusus, pp. 1-17, 2018.

[7] R. Nuqisari and E. Sudarmilah, "Pembuatan Game Edukasi Tata Surya dengan Construct 2 Berbasis Android," Emitor, vol. 19, no. 02, pp. 90-96, 2019.

[8] F. Yasin, A. Irsyadi, D. Puspitasari, and Y. I. Kurniawan, "ABAS ( Ayo Belajar Sholat ): Game Edukasi Pembelajaran Sholat Untuk Anak Tuna Rungu Wicara," vol. 9, no. April, pp. 17-28, 2019.

[9] H. A. Emka, "Game Edukasi Bahasa Indonesia Kelas 1 Sekolah Dasar Berbasis Android Menggunakan DGBL-ID Model," Integer J., vol. 2, no. 1, pp. 10-20, 2017.

[10] M. Adiwijaya, K. I. S, and Y. Christyono, "Perancangan Game Edukasi Platfrom Belajar Matematika Berbasis Android Menggunakan Construct 2," Tek. Elektro, Univ. 
Diponegoro Semarang, vol. 4, no. 1, p. 6, 2015.

[11] Y. I. K. F Y Al Irsyadi1, R Annas2, "Game Edukasi Pembelajaran Bahasa Inggris untuk Pengenalan Benda-Benda di Rumah bagi Siswa Kelas 4 Sekolah Dasar," Teknol. dan Inf., vol. 9, no. September, pp. 78-92, 2019. 